\title{
Homoaffective Loving Bond and Psychoanalysis: A Qualitative Study
}

\author{
Gustavo Chagas Oliveira ${ }^{1}$ \\ Orcid.org/0000-0002-6596-6004 \\ Maíra Bonafé Sei*, 1 \\ Orcid.org/0000-0003-0693-5029
}

${ }^{1}$ Universidade Estadual de Londrina, Londrina, PR, Brazil

\begin{abstract}
Contemporaneity encompasses several forms of conjugality, among them the relationship between people of the same sex. There are several studies on homoaffectivity and homoaffective parenting, however, few emphasize the investigation of the conjugality of these couples, especially from the psychoanalytic framework. The aim of this study was to analyze the homoaffective conjugality through the Couple and Family Psychoanalysis framework, with a focus on the bond typology and influence of generational psychic transmission. This was a clinical-qualitative study, in which four couples were interviewed, these being two pairs of women and two pairs of men, with lengths of relationship ranging from 3 to 11 years. The incidence of a bond typology of thirdness could be perceived, evidencing the capacity of these couples not to idealize the bond, exchanging different meanings about the relationship. The influence of generational psychic transmission was also observed, encouraging the members of the couples, through psychic alliances, to form their own conjugal models elaborated from previous generations. New studies aimed at the comprehension of the homoaffective conjugal bond should be carried out.
\end{abstract}

Keywords: Homoaffective couples, bond, psychic transmission.

\section{Vínculo Amoroso Homoafetivo e Psicanálise: Um Estudo Qualitativo}

\section{Resumo}

A contemporaneidade abarca diversas formas de conjugalidade e dentre elas encontra-se o relacionamento entre pessoas do mesmo sexo. Há diversos estudos sobre a homoafetividade e parentalidade homoafetiva, contudo poucos dão ênfase à investigação da conjugalidade destes casais, em especial a partir do referencial psicanalítico. Objetivou-se, assim, analisar a conjugalidade homoafetiva por meio do referencial da Psicanálise de Casal e Família, com foco na tipologia vincular e influência da transmissão psíquica geracional. Delineou-se como um estudo clínico-qualitativo, por meio do qual

* Mailing address: Rua Shangai, 55, ap. 14-B, Jardim Claudia, Londrina, PR, Brazil 86050-350. E-mail: mairabonafe@gmail.com

Support: Fundação Araucária; Conselho Nacional de Desenvolvimento Científico e Tecnológico (CNPq). 
foram entrevistados quatro casais, sendo dois casais de mulheres e dois casais de homens, o tempo de relacionamento variou entre 3 e 11 anos. Pode-se perceber a incidência de uma tipologia vincular de terceiridade, evidenciando a capacidade destes casais de não idealizarem o vínculo, intercambiando diferentes significados acerca da relação. Observou-se também a influência da transmissão psíquica geracional, incentivando os membros dos casais, através de alianças psíquicas, a constituírem modelos conjugais próprios elaborados das gerações precedentes. Novos estudos que visem a compreensão do vínculo conjugal homoafetivo devem ser realizados.

Palavras-chave: Casais homoafetivos, vínculo, transmissão psíquica.

\section{Vínculo Amoroso Homoafetivo y el Psicoanálisis: Un Estudio Cualitativo}

\section{Resumen}

La contemporaneidad abarca diversas formas de matrimonio y entre ellos es la relación entre personas del mismo sexo. Hay variados diversos estudios sobre la homoafetividad y la parentalidad homoafectiva, pero pocos ponen énfasis en la investigación de la conyugalidad de estas parejas, en especial a partir del referencial psicoanalítico. Se objetivó, así, analizar las relaciones conyugales homosexuales a través del marco de Pareja y Familia Psicoanálisis, con foco en la tipología vincular e influencia de la transmisión psíquica generacional. Se perfila como un estudio clínico-cualitativo, a través del cual los encuestados eran cuatro parejas, dos parejas de mujeres y dos parejas de hombres con relación oscilaron entre 3 y 11 años. Se puede ver la incidencia de un tipo de enlace de la terceridad, lo que indica la capacidad de estas parejas no idealizar la conexión, intercambiando diferentes significados en la relación. También señaló la influencia de la transmisión psíquica generacional, animando a los miembros de las parejas, a través de alianzas psíquicas, constituyen propios modelos maritales desarrollados a partir de las generaciones anteriores. Los nuevos estudios que busquen la comprensión del vínculo conyugal homoafectivo deben ser realizados.

Palabras clave: Parejas homosexuales, vínculo, transmisión psíquica.

Contemporaneity favors the emergence of more flexible and egalitarian conjugal configurations. This favoring takes place through social and political transformations that seek to give voice to the populations that still need visibility and rights, as is the case of the LGBT (Lesbian, Gay, Bisexual, Transvestite and Transgender) population. In Brazil, the stable homoaffective union was recognized in May 2011 by the Supreme Federal Court (Superior Tribunal Federal - STF) and the Superior Court of Justice (Superior Tribunal de Justiça - STJ). With this decision the notaries public began to carry it out, as well as convert them into civil marriages. Only in May 2013 the National Council of Justice (Conselho Nacional de Justiça - CNJ), through resolution No. 175 of 05/14/2013, began to oblige all notaries public to formalize the homoaffective civil marriage.

It is possible to find in the recent literature, published in the national scenario, several studies discussing homoaffective relationships from the perspective of the Law (Lima, 2014; Ramos \& Benigno, 2013; Vareschini, 2009). There are studies that aims to discuss homoaffective families in a broader way (Lira \& Morais, 2016; Nascimento, 2015; Rodriguez \& Gomes, 2012; Vilhena, Souza, Uziel, Zamora, \& Novaes, 2011), considering issues related to male samesex parenting (Gato \& Fontaine, 2014; Santos, Scorsolini-Comim, \& Santos, 2013) or that seek to comprehend the process of adoption by homoaffective couples (Cecílio, Scorsolini-Comin, \& Santos, 2013; Cerqueira-Santos \& Santana, 
2015; Lira, Morais, \& Boris, 2015; Rodriguez, Gomes, \& Oliveira, 2017). There are also investigations into the process of revealing the homosexual sexual orientation (Defendi, 2010; Silva, Frutuozo, Feijó, Valerio, \& Chaves, 2015), the influence of heteronormativity on the conjugality (Esteca, 2016), lesbian maternity (Pontes, Féres-Carneiro, \& Magalhães, 2015; Santos \& Gomes, 2016) and parental representation in male homoaffective couples (Rodriguez, Merli, $\&$ Gomes, 2015).

However, there are few studies on the specific subject of conjugality in homoaffective couples (Féres-Carneiro, 1997; Kurdek, 2004, 2005; Lomando, Wagner, \& Gonçalves, 2011), especially those based on the Couple and Family Psychoanalysis framework. Regarding the studies on conjugality in homosexual couples in the national scenario, Rodrigues and Boeckel (2016) found only seven articles, highlighting that the investigations still aim to "identify and describe the attitudes, convictions and principles of their participants" (p. 106). Nascimento, ScorsoliniComin, Fontaine, and Santos (2015), through a review of the international literature, highlighted the need to conduct empirical studies with this population, focusing on the particularities of homoaffective couples, faced with comparative studies that could reinforce a view based on heteronormativity.

Regarding intersubjectivity, Puget and Berenstein (1993) argue that there is an intersubjective psychic space in which ". . . the bond is privileged as a structure that permanently binds, encompasses and envelops the egos. It involves at least two, or more, and the context defined limits the specific meaning of the connected egos" (p. xi). In relation to the definition of bond, it can be said that it is a "three-term structure, consisting of two poles, the two egos (described from a virtual observer), or one ego and the other (seen from the subject himself) and a connector (or intermediary) that will handle linking both" (Puget \& Berenstein, 1993, p. 18).

For Kaës (2011), the bond refers to a ". . . more or less stable movement of the investments, of the representations and actions that associate two or more subjects to the realization of their desires" (p. 159). It presupposes a psychic work, that is, the individual needs to libidinally invest in the bond and in the other, the bond being linked to what is called intersubjective space. Conversely, love choices are related to the socalled intrasubjective space, which concerns the inner world and its relation to the object (Puget \& Berenstein, 1993)

Freud in his article "On Narcissism" (1914/1996) postulates the existence of two types of love object choice, narcissistic and anaclitic. The narcissistic choice is intimately connected with choosing someone who represents the subject himself as the love object. The individual seeks in the other what he is, was, would like to be or someone who was part of himself. On the other hand, the anaclitic choice refers to a search for the object lost in childhood, causing the individual to look for a spouse that represents the person that protected, fed and libidinally invested in him. These notes of Freud (1914/1996) focus on intrapsychic aspects, while the idea of bonding is based on an intersubjective perspective, extending the complexity around the comprehension of the conjugality.

Kaës (2014) discussed the issue of bonding between individuals through the discussion of unconscious alliances, which may have a structuring, defensive or offensive character, highlighting the role of the negative in forming of the alliances. Puget and Berenstein (1993) discuss unconscious agreements and pacts and indicated that

unconscious agreements are the result of a kind of combination between those shareable aspects, starting from each of the subjects' mental spaces, and result from the unfolding of the tendency to unify their mental and bond functions. . . . The unconscious pacts tend to specify different elements, coming from the unshareable space of each ego. Sharing the unshareable forces the egos to make a series of concessions, in order to, thus, make a pact, to meet the desire of the other, placing oneself in a favorable position. (p. 21)

The couple signs an unconscious contract through agreements and pacts and these establish 
how the couple's intersubjective relationships will work. Furthermore, Puget and Berenstein (1993) established 3 types of bond typologies: dual, broad thirdness and limited thirdness.

The dual structure refers to that in which individuals are in a bond dominated by the fusion of the couple, "dominated by the mutual idealization of some component, mostly partial" (p. 35). Limited thirdness is characterized by already having a third in the relationship, but still holding an excluded place, "there is an indiscriminate, but no longer self-sufficient, dual bond, that is, however, a producer of catastrophic anguish, avoided by the presence of the third" ( $p$. 42). Broad thirdness, in turn, shows a connection with two discriminated minds, where ". . . both have an internal representation of the other, configured so that it is not necessary to refer permanently to the other, to feel included" (p.47).

However, to understand conjugal relationships and their psychic exchanges, it is equally necessary to consider that couples carry the history of their families, that is, they have a family psychic heritage. Since Freud (1914/1996) the importance of the parental expectations deposited in the next generation has been known. In what the author named "His Majesty the Baby", parental narcissism indicates to the child the place that it must occupy to realize what the previous generation has not achieved, so that "the child will realize the golden dreams that the parents never achieved" (Freud, 1914/1996, p. 98).

Based on the Freudian formulation of parental narcissism, Aulagnier (1979) formulated the concept of the "narcissistic contract". This contract, executed between parents and children, provides a link between the generations and guarantees their continuity. Monti (2008) stated that this contract has the function of ensuring the origin of the individual, maintaining continuity between generations, enabling the development and ensuring a place for the baby.

In order to understand the influences generated by previous generations on the life of an individual and the couple, it is pertinent to discuss the concept of generational psychic transmission, which can be divided into two classes: intergen- erational and transgenerational psychic transmission (Scorsolini-Comin \& Santos, 2016). The first is linked to conscious psychic inheritances and, as such, has possibilities of elaboration, with the transmission taking place between generations. In contrast, the second refers to raw and unprocessed material transmitted unconsciously, usually linked to traumatic situations and transmitted through the generations.

It should be noted that there are several studies regarding the implications of generational psychic transmission on conjugality, as in situations in which conjugality arises prior to parenthood (Merli, 2012), on the influence of psychic transmission on the establishment of the conjugal bond (Paiva \& Gomes, 2012), considerations about this phenomenon in the parenting of homoaffective couples (Rodriguez et al., 2015, Santos \& Gomes, 2016), and even studies about individuals who choose not to construct a loving bond (Zanetti \& Gomes, 2013). However, they do not always focus on the psychic transmission of couples in conjugality unrelated to the exercise of parental functions.

Esteca (2016), in contrast, sought to comprehend the effects of heteronormativity on lesbian, childless women who had broken a homoaffective conjugal bond. The researcher observed that the participants experienced problems of rejection of the family due to their sexual orientation, as well as the influence of the psychic transmission on the relationship between the familiar concepts about homosexuality and the decisions concerning the love life of the interviewees.

Considering the existence of studies that indicate similarities in the health indices of homoaffective couples when compared with heterosexual couples, with the construction of long-term relationships (Kurdek, 2004), the aim was to analyze homoaffective conjugality in male and female homoaffective couples. Thus, through a bond analysis based on the psychoanalytic framework, the study sought to investigate four homoaffective couples and discuss the bond typology established and the defining parameters of the couple (Puget \& Berenstein, 1993), as well as the unconscious alliances established 
(Kaës, 2014 ) and the influence of the generational psychic transmission (Scorsolini-Comin \& Santos, 2016).

\section{Method}

This was a clinical-qualitative study that sought to deepen the researched subject, without focusing on the quantification and statistical analysis of data, in order to investigate the meanings and significance of the phenomena (Turato, 2003). It was configured as a strategy that makes use of concepts of psychoanalysis to delineate the research, data collection and interpretation of the results. In this type of investigation, both anguish and anxieties are valued in the study participants, and it is comprehended that "it is also the investigator's own anguish and anxieties that move him to want to understand the laws of human manifestations" (Turato, 2003, p. 252).

\section{Participants}

Four homoaffective couples participated, two couples constituted by women and two other couples made up of men, in line with Munhoz's study (2017), which also worked with data from four couples. A variety of types (Turato, 2003) was sought, when interviewing couples of men and women, however, respecting the methodological dimension of the study, which had a more exploratory nature (Fontanella \& Magdaleno, 2012) and aimed to deepen the analysis of the participants. The ages varied between 25 and 44 years and the length of the relationship varied between 3 and 11 years. The inclusion criterion was established as the minimum relationship length of 3 years (Merli, 2012), without exclusion criteria regarding social class, race or religion. All the names used in the study are fictitious, so as to preserve the identity of the participants.

\section{Data Collection}

An invitation to participate in the study was made on a social network, in both the profiles of the authors of this study and in different groups, explaining the study aims and profile of the participants and, as a result of the academic deadlines, giving the period of six months for data collection. After contact by the interested parties, the interviews were scheduled and carried out jointly, with the participation of both spouses (Merli, 2012; Munhoz, 2017). This strategy was used considering the concept of intersubjective psychic space (Puget \& Berenstein, 1993), through which it is comprehended that the bond can be analyzed if one is in the presence of the other. The interviews in question were recorded and transcribed for analysis of the data. Interview time ranged from $48 \mathrm{~min}$ to $1 \mathrm{~h} 15 \mathrm{~min}$.

\section{Instruments}

A semi-directed interview script was used (Merli, 2012) for data collection, which included questions related to the history of the couple, choice of the partner, relationship dynamics of the couple, of the parents and of the grandparents, as well as questions concerning the reaction of the family to the couple's relationship.

\section{Data Analysis}

The data analysis was performed at two different moments, with the interpretation of the material based on the psychoanalytic method, which proposes attention to the intersubjective field established in the interviews (Zanetti, 2013). It was also based on an individual analysis of each interview from categories defined a priori (Moraes, 2003) in view of the psychoanalytic framework bond adopted, which related to the couple's history, data referring to the conjugal and historical relationship of the families of source. This division aimed to contemplate discussions concerning the bond typology, conjugal dynamics established and influence of the generational psychic transmission in the conjugality of the couples interviewed (Merli, 2012). At the second moment, the data obtained in all the interviews were synthesized into a single discussion that aimed to encompass the perceptions obtained from the data set. 


\section{Ethical Aspects}

The study was submitted to the Ethics Committee for Research with Human Subjects of the State University of Londrina and was approved under authorization No. 1.031.479, with signing of the consent form by the study participants.

\section{Results}

Four couples were interviewed, two of which were made up of men and the other two women. It was hoped that the interested parties themselves would make contact with the researchers, however, only one of the couples directly contacted those responsible for the study. The other participants were indicated by colleagues or family members, who obtained information about the study through the invitation on the social network or through other means of dissemination. The interviews were carried out in the houses of the interviewees or on the premises of a university psychological clinic, according to the participants' preference.

\section{Couple 1 - Bernardo (27) and Icaro (29)}

Regarding the couple's history, Bernardo and Icaro had been together for eight years and had first met in the street when Bernardo was about 15 and Icaro 17, when they lived in neighboring towns. They were reunited 4 years later, on a social network, exchanging telephone numbers, and stayed together ever since.

Regarding the choice of partner, Icaro stated that he was identifying himself: "At first it was his personality that attracted me... The way he treated me...". Bernardo already said that it was love: "When I met him, I think he was dating and so was I. Then when I met him, I left my relationship and he did too...". They began to talk and three months later they were ready to move to a larger city.

The beginning was difficult, especially for Icaro, as he was looking for a job:

When I went to the interview I stayed a few days away from him and I felt that without him I would not manage. ... Then I got it, I did the interview, I did not discard the job and I left ev- erything right, but I told him that without him I would not go.

Bernardo agreed and reaffirmed that they could no longer live apart.

The situation in the new city was complicated, since Bernardo still did not have a job and there was no place to live. They decided to live in the house of an aunt of Icaro, who was religious, which meant that they had to hide the relationship. The reactions of family and friends to the relationship of Bernardo and Icaro were diverse. Bernardo's father was revolted at the situation, while his mother was friendly and open, this being better than he expected. Icaro did not tell his parents about his relationship until the moment he called his mother and told her, making her responsible for passing the news on to his father.

Regarding the expectations one had of the other, Icaro stated that he was very immature and Bernardo indicated that he was already more certain of what he wanted for his life. They said that financial life improved and they could invest in a business, having good financial condition at the time of the interview.

Considering the conjugal relationship, they pointed out that they had grown over the years. Icaro indicated that it was a mature relationship, with love, friendship and complicity. In consonance, Bernardo said that it was a respectful, exemplary relationship.

Regarding the conflicts faced by the couple and the ways of resolution, both agreed that the relationship was mediated by the communication between them. Bernardo indicated a balance between reason and emotion, while Icaro emphasized the importance of dialogue and also the balance between elements such as love, affection and sex.

They discussed the plan to have a child, and when asked about similarities with their parents, Icaro said that he thought that he was a bit like his mother. He said that his maternal grandparents had died, but his grandfather had been a hard, cold man, with attention given to the grandchildren by the more loving grandmother. Regarding the maternal grandparents, he highlighted the affection shared between them and 
the care of his grandfather for his wife, who was seen as weaker. On the other hand, in relation to the parents, Icaro reported that they fought a lot, despite the love they felt for each other, with his mother always telling him about their fights.

Bernardo reported that he did not have much information about his paternal grandparents, because his grandfather passed away very early. He talked about his maternal grandparents, about the constant quarrels and the separation that occurred when they were elderly. His parents were united and loved each other very much, however, they had already been through many conflicts. They dated when they met, similar to Bernardo and Icaro, establishing a relationship that was permeated by fights and the use of alcohol by his father. There were episodes of violence, however, at the time of the interview they got along well, traveled and had a positive relationship.

\section{Couple 2 - Alice (44) and Helena (37)}

Regarding the couple's background, they had been together for 11 years and had met in a bar through a mutual friend. Helena and this friend decided to study together in the apartment that this friend shared with Alice, so that they began to see each other often. Alice reported that from the first day she saw Helena she was interested in her. Helena, for her part, said that Alice had caught her attention, but that she had never been in a relationship with another woman.

Alice arranged for them to be alone at one of these meetings and Helena explained that at that moment she decided to surrender to what she was feeling. Helena was involved in a heterosexual relationship before meeting Alice and reported that the beginning of their relationship she felt like she was "entering into another universe".

In relation to their decision to live together, Alice explained that they slept together daily, with Helena attributing the swiftness of living together to the fact that they were lesbians. Alice nodded and said, "The lesbian already has a box packed that she takes to the other's house straight away". Helena said the couple had a "logistics that works" and Alice indicated that there was respect for "space and time".

Regarding the expectations for the relationship, Alice highlighted that she could not imagine anything different from what she already was. Helena, on the other hand, said that there was a strangeness at first, but that she gradually became "fascinated" by Alice.

Regarding the family's reaction to the couple's relationship, Alice said on her part it was calm, since her parents had known about her sexual orientation since she was an adolescent. For Helena the story unfolded differently, with her mother having reacted badly, especially due to the understanding that this relationship coincided with the death of Helena's father. According to her, "as I had already lost a brother tragically, there were two tragic deaths in a space of five years. . . After a while my mother was assimilating". Alice added that they now had the feeling that the family was complete.

Considering the conjugal relationship in general, Alice stated that there was much happiness: "We have crises, we argue about a lot of things, but we have a lot of fun too. . . It's a fluid thing, a very good thing". Helena added that: "We understood at one point that our ways were different and we found common spaces to enjoy".

In relation to the communication and the conflicts between the couple, Helena explained that they had been through difficult times, but with dialogue and the search for the best solution to the conflicts experienced:

I have an exercise of saying what you feel. My mother and I talk a lot. We have a habit of sitting and talking. Alice's family does not talk... And that reflected strongly on us both, because now she speaks more.

The couple reported having difficulty in deciding to have children or not, since Helena wanted to have a child, without imagining that she would not have: "And so, I lost a brother and lost a father too.... In addition to a desire to have a child, I had a feeling of loss of family". Alice, for her part, never imagined having children and argued that: "thinking for myself about having a child seems like I'm going to stop experiencing some things". 
Helena reported that the construction and maintenance of the conjugality was related to the care with certain issues to be cultivated in the relationship, without an automatism of the relationship, as well as the respect for the individual spaces. Alice explained that it was necessary to try to "balance to stay good".

When asked about appearing similar to their parents in their relationship, Helena affirmed an identification in the field of the partnership of the couple, with a distancing from this model as a result of not liking to fight, like her parents did. Alice reported that she needed to: "control the thing of my mother, she's very caring. Sometimes I question myself and I think some things are repeated, but I think it is important to see this. It does not go unnoticed".

Regarding the families of origin, Alice said that she did not have much information about the paternal grandparents, since they had died very early. She was close to her maternal grandmother, who suffered from harshness and verbal aggression from her husband, seen as a "man who did not know the pleasures of life". Regarding the parents, Alice said that they formed a "cool" couple, without fights and that did activities together, "One does not live without the other". As for Helena, she said that her father's family was always "stronger" than her mother's family: "My grandmother used to say that she liked to order and that my grandfather liked to be ordered. She is the great matriarch of the family, but she caused a lot of people to go to therapy. Me included". About the maternal grandparents, Helena said that they had a tumultuous history:

He was a macho man and she was a very good woman. They had two children, my carefree mother and my uncle who was gay. Something tied up in my life. My mother's history is a sequence of tragedies. Her brother died of HIV, she was losing everything in a tragic way. That's why people got so angry that I became a dyke.

Regarding the parents, Helena said they met on the bus as a result of their work and study commitments. Her father had a history of depression, while her mother was always vivacious.
He fell in love with this thing about her and she fell in love because he was different from the men she had known... . They were two very intense people and I say that there was no mediator there... My brother ended up committing suicide when he was 22 and I see that it was a journey of life dealing with the shocks that my brother caused. They had disagreements... This thing of the problem child was took the stability from the couple. They disagreed with each other, so much so that when my brother killed himself their marriage turned horrible. But they were always in love, they traveled a lot and I have a lot of this... Nowadays my mother has returned to being this incredible person, more alive, fun. I did not know that my mother was fun, it was my father who brought a little music to the house.

\section{Couple 3 - Miguel (34) and Vicente (31)}

Considering the history of the couple, Miguel and Vicente, together for six years, lived in neighboring cities and met through a post of a friend in common on a social network. Initially they saw each other every 15 days. After 6 months of dating, Miguel moved to the same city as Vicente and the two began to live together. In relation to the beginning of the relationship, Vicente reported that he was more resistant, taking time to admit his feelings. Already Miguel had had difficulty accepting that he liked Vicente, as he had never been in a homoaffective relationship:

We have been gay since we were born, but sometimes you are reluctant. The worst acceptance, the most difficult, was my own acceptance. . . Then I thought, "I'll allow myself". That's when I met him, the first and only partner I ever had.

Regarding expectations about the relationship, Vicente said that he did not create expectations and sought not to idealize, in a similar way to Miguel, who indicated that he had not created expectations, knowing how the relationship would be after six months of living together. 
The decision to live together was due to the need to be together in the same city, with Miguel having to look for a better job. However, "the big question of thinking about us, thinking about a future relationship, was when we bought the apartment". Until then, the couple shared the expenses of a rented apartment. When the opportunity arose to buy their own apartment, Miguel hesitated: "It was only a year since we had started living together. I wanted to buy mine, because if we finished I would have mine".

Regarding the family's reaction to the relationship, Miguel was reluctant to tell his parents, but stated that they knew about his relationship with Vicente. Vicente said that in his case he had already told his parents some time ago about his sexual orientation.

The conjugal relationship was seen as calm, however, there were situations in which they disagreed. Miguel said: "We do not fight . . . I do not have much patience, sometimes I start a fight, but he only listens, then it loses the point, and it's no fun to fight alone, right?" Vicente, for his part, said: "We do not have stress. I see that most couples have problems with jealousy, prohibiting, and we usually do everything together or we have the opening of one doing and one not". Miguel indicated the routine of the couple was well organized and each had his role: "At home there is a division of tasks... ... Its cool, we divide things. There is not that thing where one is the slave, so we do not create conflict".

Regarding the communication between the couple, they highlighted their differences in dealing with situations, since Vicente was more introspective in the day to day, with difficulty speaking about what happened, while Miguel talked more. The couple did not experience much conflict, however, there had already been problems on some occasions due to the jealousy of both. The need for negotiation for the maintenance of the conjugality was highlighted by both. Miguel indicated that it was necessary to learn to give in and Vicente completed that saying that there should be a "consensus", with the capacity to "Put yourself in the other's place".
Considering the similarities with his parents, Miguel replied that Vicente was like his father:

Sometimes he changes and speaks loudly and I tell him that I am not his mother. . . . He's a lot like his dad, just like I think I'm a bit like my dad. And I think he's a bit opposite to his mother. His mother is a little detached from him.

When Miguel spoke about Vicente's mother, he replied that he and his sister were always very independent: "As I came here to study and lived alone, I had to look after myself. So much so that she only came to visit the other day, 10 years later".

As far as his paternal grandparents were concerned, Miguel knew that his grandfather was an Italian immigrant, having been very severe, giving the impression that "he made a son to work for him" and he remembered his mother saying that his maternal grandfather was aggressive and used alcohol. He though he resembled his father, seen as "a bit critical". Vicente said that the maternal and paternal grandparents met working in the rural area, with the paternal grandparents having married early and the grandmother being a very young mother, with the couple separating afterwards. The maternal grandparents constantly changed their city as a result of their work in the fields. Vincent's parents separated when he was a teenager, attributing the separation to the fact that his father was harsh and aggressive. They were distant, but at the time of the interview they got along well.

\section{Couple 4 - Clara (41) and Manuela (25)}

The couple, together for three years, met through a mutual friend who went to college with Clara, having started the relationship shortly after Clara separated from her ex-husband, with the relationship beginning a few days after Clara left home: "It was kind of meteoric". Regarding the choice of partner, Manuela spoke about her preference for older women as a factor for being with Clara, unlike Clara who, faced with separation, did not expect to become involved with anyone. 
In relation to them choosing to live together, Manuela reported that the situation made them live together after six months of dating. They indicated that Manuela's mother reacted "very well" to the knowledge of the relationship, unlike Clara's family who presented a negative reaction, considering she was leaving a relationship and assuming her sexual orientation. She had already tried to admit her homosexuality at the age of 18, having told her sister and mother, who threatened to kill herself. She ended up marrying at the age of 23 , a fact that calmed her family and the rumors in the city, but led to the use of alcohol "for relief", as well as insomnia, headaches and asthma, with her health reflecting her emotional state. She tried to break away from this relationship when her son was three years old, not having done so due to reminding herself of her father leaving home when she was little and of the anger generated by him having left her with her mother who was an extremely difficult person. When her son was 15 , they talked and he encouraged her to separate, with her mother and sister again opposing her choice.

Regarding the expectations about the relationship, Manuela said: "Clara is kind of captious, you know? So I figured it would not be easy" and Clara explained saying,

When she says captious, it's because of the organization of the house... . . . In attempting to keep everything right, organized, within that marriage, inside that little box, I became neurotic about things of the house. So when I went to live with Manuela I had to unlearn many things.

They got along very well, with sporadic fights, however, Clara remembered the past difficulties, especially the financial ones, experienced together. Manuela was very jealous, however, as Clara had not had dated many people the relationship worked. Manuela also pointed out that she was difficult, starting fights for silly things. Manuela told me that she was used to being quiet and thought it would not work, because she was a difficult person.

They thought of buying a house, getting married and, according to Clara, she wanted to persuade Manuela to have a child, indicating the fear of the birth presented by the partner. They both agreed that trust was needed in each other so that the relationship could be maintained. Regarding age, Manuela stated: "It does not feel like an age difference".

In relation to the similarity with the parents, Manuela said she did not see this: "my stepfather is very possessive. I do not think at all that my relationship is similar to that of my mother and my stepfather". Clara, in turn, reported a similarity to her father.

I think I've never been so much like my father as I am now. Not so much in the relationship, but the experience of having been cursed by the family. He because of the disease of alcoholism and I because of homosexuality, that in their heads, they see as the same.

Clara said that her paternal grandparents had moved out of town as a result of her grandmother having married the best friend of her former fiancé after being incorrectly told about the death of this fiancé in the war. Of her maternal grandparents, Clara reported that her grandmother was a retiring woman, who had come to work in the coffee plantations in the southeast of the country, and had married the son of the administrator of the farm where she worked. Clara's relationship with her grandmother was quite close, with her having played a maternal role for Clara. Regarding her parents, she indicated that they had dated for eight months, they got married, living well until Clara was ten years old. Her father had been an alcoholic since the courtship, leaving home and returning years later.

Concerning her paternal grandparents, Manuela had no data. Regarding her maternal grandparents, she reported that her grandmother was married to another man she called grandfather, without ever knowing about her biological grandfather. Regarding the story of her parents' relationship, Manuela explained that she did not have much contact with her father because he and her mother had never been married. 


\section{Discussion}

It was decided that a joint discussion of the four interviews would be presented, evidencing aspects of each couple, similarities and differences between them, with indications related to the typing, conjugal dynamics and influences of the generational psychic transmission on the conjugality of the interviewees. In this sense, it was noted that in all the couples the bond was established rapidly, as was living together. Couple 2 attributed the speed, in addition to the affection, to the fact that they were lesbian, positioning that indicates the construction of a homoaffective identity in this couple, highlighting what they comprehended to be characteristics of this loving arrangement. Bernardo (Couple 1), on the other hand, reported always explaining that his relationship with Icaro was like any other (Kurdek, 2004, 2005) and that people viewed homoaffective relationships as promiscuous, highlighting the social stigma experienced from the sexual orientation behavior and that could have negative consequences for the couple (Doyle \& Molix, 2015; Esteca, 2016; Rostosky \& Riggle, 2017).

The family, in turn, plays an important role in the experience of homoaffectivity. Icaro (Couple 1), Helena (Couple 2), Miguel (Couple 3) and Clara (Couple 4) reported facing difficulties in telling their family about their sexual orientation. The influence of parental expectations and the narcissistic contract (Aulagnier, 1979; Freud, 1914/1996; Monti, 2008) on the lives of these individuals was therefore perceived, since assuming homosexuality would be tantamount to breaking with this unconscious contract and possibly with the family bond, as exposed by Clara who felt the family had castigated her. The influence of heteronormative patterns on the discourse of the families (Esteca, 2016) and the intense conflicts arising from this need for adaptation to the patterns can be seen in the cases of Miguel (Couple 3) and Clara (Couple 4), who were in previous heterosexual relationships, although they had already recognized a desire in themselves for same sex partners.
The beginning of the relationship of Couple 1 was marked by a great emotional dependence, since they reported that they could not live without each other, and it is possible to think of a dual structure bond (Puget \& Berenstein, 1993), in which there is an indiscrimination in the bond, a need to refer to each other to feel included. However, with the maturation of the couple, they were able to plan the entry of a third element in reporting the desire for parenthood, and could highlight the establishment of a bond of thirdness, without data to characterize it as limited or broad thirdness. Couple 2, in turn, highlighted the differences between the partners. Helena affirmed that there was a mutual understanding regarding the possibility of dedication to individual activities, taking care, however, to develop common spaces to share the conjugality, with plans shared between both on a daily basis and an apparent balance between the individual and the conjugal. These dynamics can refer to a broad thirdness type of relationship (Puget \& Berenstein, 1993), as it evidences the presence of communication in order to elaborate the conflicts experienced, with the preservation and respect for the individuality of each person.

The couple also showed that both had different attitudes to the relationship, but that they were able to reach an agreement. There was no bond maintained by idealization, since each also highlighted things in the other that did not please him/her, and a structure of broad thirdness could be perceived (Puget \& Berenstein, 1993). It is believed that Couple 4 also organized around a typology of broad thirdness, since both reported how they perceived themselves and how they perceived the other, showing, however, their differences and respect for the other, with the necessary concessions to the experience together.

Generational marks could be observed at different times, such as in Couple 1, whose relationship began in a similar way to that of Bernardo's parents, since both gave up their previous relationships in order to be together. Clara (Couple 4) stated that she used alcohol during her first marriage and wanted to leave 
home, like her own father, an aspect she herself observed. Miguel (Couple 3) said that he used to complain about things, similar to his father, and had even pointed out the similarities between his spouse Vicente and his father, recalling the anaclitic choice proposed by Freud (1914/1996). Alice (Couple 2) explained that she was not a person who used to talk a lot, having related this factor to the dynamics of her family. The opposite was the case for Helena, who claimed to have a communicative family. These aspects are related to what is transmitted psychically between the families, whether in relation to conscious aspects, with the family of origin as a model of identification, or through unconscious contents, influenced by unconscious pacts (Kaës, 2014) and transgenerational psychic transmission (Scorsolini-Comin \& Santos, 2016).

The family histories of almost all the participants were permeated by conflicts, which left imprints on the relationships. However, it was generally observed that the couples did not face or had faced such adverse situations regarding their past families. Icaro (Couple 1) referred to the relationship with Bernardo as "matured". Helena (Couple 2) rejected her parents' conflictive past, but indicated a similarity regarding her strong partnership established with Alice. Miguel and Vicente (Couple 3) sought to understand and establish a consensus between the two when they had fights. Clara and Manuela (Couple 4) made agreements about the dynamics of the house and reported living together harmoniously.

It was considered that these couples brought elements of their families of origin to the conjugality (Merli, 2012), however, seemed to have appropriated and elaborated part of this heritage (Paiva \& Gomes, 2012; Scorsolini-Comin \& Santos, 2016), seeking to create a conjugal model of their own (Rodriguez et al., 2017). Despite the particularities of each couple, the presence of a more mature bond typology, of the thirdness type, can be highlighted, in which there were conditions to accommodate the differences between the members, without the fusion experience characteristic of the dual structure (Puget $\&$ Berenstein, 1993). This reinforces, therefore, the questions about possible psychopathological traits and stereotyped views that can be attributed to this population (Munhoz, 2017).

Finally, it is thought that same-sex couples end up facing situations through which heterosexual couples would not pass, such as the nonacceptance of the family, as this comes specifically from the homoaffectivity, as highlighted by Steca (2016), indicating that this fact implies negative consequences for the affective relationship. It is recalled that the difficulties faced by homoaffective couples extend beyond the family context, with problems also centered on the social scene, where the relationship cannot always be assumed in a free, open way. That is, in addition to the non-acceptance of the spouse by the family, something that can occur in heterosexual couples, it is understood that this rejection comes loaded with other implications arising from the social field. In this sense, it is believed that if the expression of affection in the public space can present itself as something constrained for these couples, there are impediments in relation to the acceptance and possibility of expression of affectivity also in the private, familiar field. This fact may imply psychological suffering of this population, not due to the typology established in the loving pair, but due to factors extrinsic to the relationship.

In general, heteronormative patterns are still very much present, either in the design of studies that seeks to compare homosexual and heterosexual couples (Nascimento et al., 2015; Rodrigues \& Boeckel, 2016), or in the relationship established (Munhoz, 2017), reflecting on different ways for the construction of the conjugality, a search highlighted by the couples studied. It is understood, therefore, that homoaffective couples are inserted in different contexts and, therefore, studies are needed that contemplate their experiences (Nascimento et al., 2015). As argued by Rodrigues and Boeckel (2016, p. 107), "the comprehension and reflection of the different forms of conjugality beyond the traditional heteronormative model can be of great relevance in the intervention actions in Psychology", emphasizing the clinical importance of this detailed analysis of the dynamics of these couples. 
However, it is recognized that there are limitations regarding the size and heterogeneity of the sample, composed of only four couples two of women and two of men - as well as not addressing elements related to socioeconomic class, race and religion, comprehending that these may be aspects that influence the nature of the data collected. The limits also refer to the fact that the data were obtained through a single in-depth interview that, in spite of the gains for the couples coming from the joint interview (Merli, 2012), which provides knowledge about previous histories, discussion about the conjugality and appropriation of previously unknown contents, constitutes a section of this experience, different to what would happens when dealing with clinical material coming from a process of psychotherapeutic with these couples. Thus, a closed analysis of the data was not sought, but rather a discussion that fostered interest in the undertaking of new studies.

With regard to proposals for studies with similar populations, investigations are proposed that work with larger samples, which could compare results considering socioeconomic class, race and religion. The development of studies that make use of clinical material coming from couple psychotherapy with this public or through interviews with couple psychotherapists that attend homoaffective couples is also understood to be equally relevant, as this would enrich the understanding of the conjugal dynamics of these couples.

\section{References}

Aulagnier, P. (1979). A violência da interpretação. Rio de Janeiro, RJ: Imago.

Cecílio, M. S., Scorsolini-Comin, F., \& Santos, M. A. (2013). Produção científica sobre adoção por casais homossexuais no contexto brasileiro. Estudos de Psicologia (Natal), 18(3), 507516. doi: https://dx.doi.org/10.1590/S1413294X2013000300011

Cerqueira-Santos, E., \& Santana, G. (2015). Adoção homoparental e preconceito: Crenças de estudantes de direito e serviço social. Temas em Psicologia, 23(4), 873-885. doi: http://dx.doi. org/10.9788/TP2015.4-06
Conselho Nacional de Justiça. (2013, May 14). Resolution No. 175 of 05/14/2013. Dispõe sobre a habilitação, celebração de casamento civil, ou de conversão de união estável em casamento, entre pessoas de mesmo sexo. Retrieved from http://www.cnj.jus.br/busca-atosadm?documento $=2504$

Defendi, E. L. (2010). Homoconjugalidade masculina, revelação e redes sociais: Um estudo de caso (Master thesis, Pontifícia Universidade Católica de São Paulo, SP, Brazil).

Doyle, D. M., \& Molix, L. (2015). Social stigma and sexual minorities' romantic relationship functioning: A meta-analytic review. Personality and Social Psychology Bulletin, 41(10), 1363-1381. doi: http://journals.sagepub.com/ doi/10.1177/0146167215594592

Esteca, F. M. (2016). Impactos da heteronormatividade sobre a conjugalidade lésbica: Uma análise psicanalítica a partir do relato de mulheres separadas (Doctoral dissertation, Universidade de São Paulo, SP, Brazil).

Féres-Carneiro, T. (1997). A escolha amorosa e interação conjugal na heterossexualidade e na homossexualidade. Psicologia: Reflexão e Crítica, 10(2), 351-368. doi: http://dx.doi.org/10.1590/ S0102-79721997000200012

Fontanella, B. J. B., \& Magdaleno, R., Jr. (2012). Saturação teórica em pesquisas qualitativas: Contribuições psicanalíticas. Psicologia em Estudo, 17(1), 63-71. doi: https://dx.doi.org/10.1590/ S1413-73722012000100008

Freud, S. (1996). Sobre o narcisismo: Uma introdução. In S. Freud, Obras psicológicas completas de Sigmund Freud: Edição standard brasileira (pp. 81-108). Rio de Janeiro, RJ: Imago. (Original work published in 1914)

Gato, J., \& Fontaine, A. M. (2014). Homoparentalidade no masculino: Uma revisão da literatura. Psicologia \& Sociedade, 26(2), 312-322. doi: https://dx.doi.org/10.1590/S010271822014000200008

Kaës, R. (2011). A realidade psíquica do vínculo. $R e$ vista Brasileira de Psicanálise, 45(4), 155-166.

Kaës, R. (2014). As alianças inconscientes. São Paulo, SP: Idéias \& Letras.

Kurdek, L. A. (2004). Are gay and lesbian cohabiting couples really different from heterosexual married couples?. Journal of Marriage and Family, 
66(4), 880-900. doi: https://doi.org/10.1111/ j.0022-2445.2004.00060.x

Kurdek, L. A. (2005). What do we know about gay and lesbian couples?. Current Directions in Psychological Science, 14(5), 251-254. doi: https:// doi.org/10.1111/j.0963-7214.2005.00375.x

Lima, J. E. A. (2014). Homoafetividade sob a ótica do direito no Brasil. Critério Jurídico, 14(1), 44-69. Retrieved from http://revistas.javerianacali.edu.co/index.php/criteriojuridico/article/ view/1124/1711

Lira, A. N., \& Morais, N. A. (2016). Famílias constituídas por lésbicas, gays e bissexuais: Revisão sistemática de literatura. Temas em Psicologia, 24(3), 1051-1067. doi: https://dx.doi. org/10.9788/TP2016.3-14Pt

Lira, A. N., Morais, N. A., \& Boris, G. D. J. B. (2015). A homoparentalidade em cena: A vivência cotidiana de mulheres lésbicas com seus filhos. Revista da SPAGESP, 16(1), 74-91. Retrieved from http://pepsic.bvsalud.org/scielo.php?script=sci_ arttext\&pid=S1677-29702015000100007

Lomando, E., Wagner, A., \& Gonçalves, J. (2011). Coesão, adaptabilidade e rede social no relacionamento conjugal homossexual. Psicologia: Teoria e Prática, 13(3), 96-109. Retrieved from http://pepsic.bvsalud.org/scielo.php?script=sci arttext\&pid=S1516-36872011000300008\&lng= pt\&tlng $=\mathrm{pt}$

Merli, L. F. (2012). Quando a conjugalidade surge antes da parentalidade (Master thesis, Instituto de Psicologia, Universidade de São Paulo, SP, Brazil).

Monti, M. R. (2008). Contrato narcisista e clínica do vazio. Revista Latinoamericana de Psicopatologia Fundamental, 11(2), 239-253. doi: http:// dx.doi.org/10.1590/S1415-47142008000200006

Moraes, R. (2003). Uma tempestade de luz: A compreensão possibilitada pela análise textual discursiva. Ciência \& Educação (Bauru), 9(2), 191-211. doi: https://dx.doi.org/10.1590/S151673132003000200004

Munhoz, D. B. (2017). A constituição do vínculo e o legado familiar heteronormativo em casais homossexuais longevos, femininos e masculinos (Doctoral dissertation, Universidade de São Paulo, SP, Brazil).

Nascimento, G. C. M., Scorsolini-Comin, F., Fontaine, A. M. G. V., \& Santos, M. A. (2015). Re- lacionamentos amorosos e homossexualidade: Revisão integrativa da literatura. Temas em Psicologia, 23(3), 547-563. doi: https://dx.doi. org/10.9788/TP2015.3-03

Nascimento, M. (2015). "O amor entre iguais também forma família": Uma experiência de trabalho com famílias homoafetivas. Nova Perspectiva Sistêmica, 24(51), 127-129. Retrieved from http:/www.revistanps.com.br/index.php/nps/ article/view/181/156

Paiva, M. L. S. C., \& Gomes, I. C. (2012). La transmission psychique et la constitution du lien conjugal. Revue de Psychothérapie Psychanalytique de Groupe, 58(1), 81-90. doi: https:// dx.doi.org/10.3917/rppg.058.0081

Pontes, M. F., Féres-Carneiro, T., \& Magalhães, A. S. (2015). Famílias homoparentais e maternidade biológica. Psicologia \& Sociedade, 27(1), 189-198. doi: https://dx.doi.org/10.1590/180703102015v27n1p189

Puget, J., \& Berenstein, I. (1993). Psicanálise do casal. Porto Alegre, RS: Artes Médicas.

Ramos, D. P., Jr., \& Benigno, E. P. (2013). Casamento homoafetivo no Direito Brasileiro e no Direito Comparado: Tendências segundo uma visão histórica, econômica e antropológica. Revista Jurídica Cesumar-Mestrado, 13(2), 581-609. doi: http://dx.doi.org/10.17765/21769184.2013v13n2p\%25p

Rodrigues, V., \& Boeckel, M. (2016). Conjugalidade e homossexualidade: Uma revisão sistemática de literatura. Nova Perspectiva Sistêmica, 25(55), 96-109. Retrieved from http://www.revistanps. com.br/index.php/nps/article/view/138/142

Rodriguez, B. C., \& Gomes, I. C. (2012). Novas formas de parentalidade: Do modelo tradicional à homoparentalidade. Boletim de Psicologia, 62(136), 29-36. Retrieved from http:// pepsic.bvsalud.org/scielo.php? script $=$ sci_ arttext\&pid=S0006-59432012000100004\&lng= pt\&tlng $=\mathrm{pt}$

Rodriguez, B. C., Gomes, I. C., \& Oliveira, D. P. (2017). Família e nomeação na contemporaneidade: Uma reflexão psicanalítica. Estudos Interdisciplinares em Psicologia, 8(1), 135-150. doi: http://dx.doi.org/10.5433/22366407.2017v8n1p135

Rodriguez, B. C., Merli, L. F., \& Gomes, I. C. (2015). Um estudo sobre a representação parental de 
casais homoafetivos masculinos. Temas em Psicologia, 23(3), 751-762. doi: https://dx.doi. org/10.9788/TP2015.3-18

Rostosky, S. S., \& Riggle, E. D. (2017). Same-sex relationships and minority stress. Current Opinion in Psychology, 13, 29-38. doi: https://doi. org/10.1016/j.copsyc.2016.04.011

Santos, C. V. M., \& Gomes, I. C. (2016). The L Word - Discussões em torno da parentalidade lésbica. Psicologia: Ciência e Profissão, 36(1), 101-115. doi: https://dx.doi.org/10.1590/19823703000092014

Santos, Y. G. S., Scorsolini-Comin, F., \& Santos, M. A. (2013). Homoparentalidade masculina: Revisando a produção científica. Psicologia: Reflexão e Crítica, 26(3), 572-582. doi: https:// dx.doi.org/10.1590/S0102-79722013000300017

Scorsolini-Comin, F., \& Santos, M. A. (2016). Construir, organizar, transformar: Considerações teóricas sobre a transmissão psíquica entre gerações. Psicologia Clínica, 28(1), 141159. Retrieved from http://pepsic.bvsalud.org/ scielo.php?script $=$ sci_arttext\&pid $=\mathrm{S} 0103$ $56652016000100008 \& \operatorname{lng}=p t \& t \operatorname{lng}=p t$

Silva, M. M. L., Frutuozo, J. F. F., Feijó, M. R., Valerio, N. I., \& Chaves, U. H. (2015). Família e orientação sexual: Dificuldades na aceitação da homossexualidade masculina. Temas em Psicologia, 23(3), 677-692. doi: https://dx.doi. org/10.9788/TP2015.3-12

Turato, E. R. (2003). Tratado da metodologia da pesquisa clínico-qualitativa: Construção teóricoepistemológica, discussão comparada e aplicação nas áreas da saúde e humanas. Petrópolis, RJ: Vozes.
Vareschini, J. M. L. (2009). O reconhecimento jurídico da união entre pessoas do mesmo sexo. Cadernos da Escola de Direito e Relações Internacionais, 2(11), 302-340. Retrieved from http://revistas.unibrasil.com.br/cadernosdireito/ index.php/direito/article/view/757/711

Vilhena, J., Souza, A. C. B., Uziel, A. P., Zamora, M. H., \& Novaes, J. V. (2011). Que família?: Provocações a partir da homoparentalidade. Revista Mal Estar e Subjetividade, 11(4), 16391658. Retrieved from http://pepsic.bvsalud. org/scielo.php?script $=$ sci_arttext\&pid $=\mathrm{S} 1518$ $61482011000400014 \& \operatorname{lng}=\mathrm{pt} \& \operatorname{lng}=\mathrm{pt}$

Zanetti, S. A. S. (2013). O método psicanalítico: Quando a pesquisa pode contar com uma escuta permeável ao inconsciente. In Anais do I Encontro de Pesquisa Clínico-Qualitativa e I Jornada do LEPPSI: Interlocução de saberes, desafios e descobertas na trajetória da pesquisa (pp. 2530). Londrina, PR: Universidade Estadual de Londrina.

Zanetti, S. A. S., \& Gomes, I. C. (2013). Vínculos amorosos contemporâneos frágeis. OMNIA Saúde, 10(1), 36-45. Retrieved from http://www.fai. com.br/portal/ojs/index.php/omniasaude/article/ view/465/645
Received: 03/01/2017

$1^{\text {st }}$ revision: $10 / 07 / 2017$

$2^{\text {nd }}$ revision: $23 / 10 / 2017$

$3^{r t}$ revision: 04/12/2017

Accepted:21/02/2018

(c) BY 1 (C) The Author(s), 2018. Open Access. This article is distributed under the terms of the Creative Commons Attribution 4.0 International License (http://creativecommons.org/licenses/by/4.0/), which permits unrestricted use, distribution, and reproduction in any medium, provided you give appropriate credit to the original author(s) and the source, provide a link to the Creative Commons license, and indicate if changes were made. 